Français, anglais et allemand: trois langues rivales entre 1850 et 1945. French, English and German: three languages in competition between 1850 and 1945

\title{
Languages, choice of languages, and other priorities in the Leathes Report to the British Government (1918)
}

Michael Byram

\section{(2) OpenEdition Journals}

\section{Édition électronique}

URL : https://journals.openedition.org/dhfles/4023

DOI : $10.4000 /$ dhfles.4023

ISSN : 2221-4038

Éditeur

Société Internationale pour l'Histoire du Français Langue Étrangère ou Seconde

Édition imprimée

Date de publication : 1 décembre 2014

Pagination : 153-173

ISSN : 0992-7654

Référence électronique

Michael Byram, «Languages, choice of languages, and other priorities in the Leathes Report to the British Government (1918) ", Documents pour l'histoire du français langue étrangère ou seconde [En ligne], 53 | 2014, mis en ligne le 05 septembre 2017, consulté le 28 mai 2021. URL : http:// journals.openedition.org/dhfles/4023; DOI : https://doi.org/10.4000/dhfles.4023

Ce document a été généré automatiquement le 28 mai 2021

(c) SIHFLES 


\title{
Languages, choice of languages, and other priorities in the Leathes Report to the British Government (1918)
}

\author{
Michael Byram
}

\section{Introduction}

1 The Leathes Report (the abbreviated designation for "The Report of the Committee Appointed by the Prime Minister to Enquire into the Position of Modern Languages in the Educational System of Great Britain", chaired by Stanley Leathes ${ }^{1}$ ) was published in 1918. The Leathes committee was one of four subcommittees dealing with the modernisation of education under a general Reconstruction Committee formed in response to calls for a review of education which had become particularly strong in 1916 (Bayley 1991: 16). The committee had been charged to enquire into "Modern Languages" in secondary schools and universities, "regard being had to the requirements of a liberal education and appreciation of the history, literature and civilisation of other countries, and to the interest of commerce and public service" (Leathes Report 1918: 1). Already in these terms of reference, two purposes of language teaching are clearly established, "liberal education" and "the interest of commerce and public service". Furthermore, in the definition of terms, which immediately follows, the relationship of the study of language to "the study of modern peoples in any and every aspect of their national life" is clarified. It is emphasised that "the study of languages is, except for the philologist, always a means and never an end in itself" (ibid.).

2 In this chapter, I will analyse the consequences of this view of language teaching with respect to the choice of language to be taught and, secondly, with respect to the implications for language teaching methodology of the distinction between language teaching and the teaching of "Modern Studies". For it is important to note that, though 
asked to consider the important position occupied by "Modern Languages in the educational system of Great Britain" in the terms of reference, the Report in fact focuses on the more inclusive term "Modern Studies". I will then go further and locate the report and its ideology in the broader context of education in post-war Europe and in Britain in particular. Here my interest is in the relationship of the Report to a need for "internationalism" in education as felt by some of the actors of the time.

\section{Context}

Bayley (1991) provides an account of the provenance and reception of the Leathes Report within the national context. There had been debate about the role and possible culpability of the education system in failing to anticipate what eventually became known as the First World War, and in how it was conducted. In particular, failure to meet the need for linguists to support cooperation with allies was the subject of comment in society at the time. The Report itself suggests that a poor knowledge of German and Germany was significant: "Ignorance of the mental attitude and aspirations of the German people may not have been the cause of the war; it certainly prevented due preparation and hampered our efforts after the war had begun; it still darkens our counsels" (Leathes Report 1918: 11). The reference to darkened counsels was an unwitting prediction of the attitudes later to dominate the Treaty of Versailles and the exorbitant demands for reparations, and an element of the 'structure of feeling' of the times, those 'formally held and systematic beliefs' and the 'meanings and values as they are actively lived and felt' (Williams 1977: 132).

4 Keynes was aware of this feeling at Versailles and was withering in his criticism of the Treaty. He characterises the economic relationship of Britain to Europe in a way which would not be out of place today; for Keynes a European outlook should be more important than British preoccupations:

For one who spent in Paris the greater part of the six months which succeeded the Armistice an occasional visit to London was a strange experience. England still stands outside Europe. Europe's voiceless tremors do not reach her. Europe is apart and England is not of her flesh and body. But Europe is solid with herself. France, Germany, Italy, Austria and Holland, Russia and Roumania and Poland, throb together, and their structure and civilization are essentially one. [...] At any rate an Englishman who took part in the Conference of Paris and was during those months a member of the Supreme Economic Council of the Allied Powers, was bound to become, for him a new experience, a European in his cares and outlook. There, at the nerve centre of the European system, his British preoccupations must largely fall away and he must be haunted by other and more dreadful spectres. (Keynes 1920:4)

5 The Leathes Report reveals however no hint of a Keynesian European or international perspective, as we shall see in more detail below. It maintains an attitude of separation and yet this might have been, perhaps ought to have been, questioned by a committee concerned with "liberal education" as one of five significant dimensions of language teaching and learning.

Before identifying these five dimensions, the Report begins its account of the enquiry by making the point that its scope should be wider than the original remit and should deal with Modern Studies and not just modern foreign languages. The definition of 
Modern Studies is presented already in the letter of introduction to the Report addressed to Prime Minister Lloyd George:

We shall use the term "Modern Studies" to signify all those studies (historical, economic, literary, critical, philological, and other) which are directly approached through modern foreign languages. "Modern Studies" are thus the study of modern peoples in any and every aspect of their national life, of which the languages are an instrument as necessary as hands, and feet, and heart, and head. The term may sometimes be used in this Report for the study of one or more languages without consideration of ulterior aims, but it is well to remember that the study of languages is, except for the philologist, always a means and never an end in itself. (Leathes Report 1918: 2)

7 Once the question of remit has been clarified, the criteria used in the debate about the value of Modern Studies are presented:

- the business value;

- the increase of knowledge in general;

10 - the need for knowledge concerning foreign countries and peoples;

11 - knowledge important for the public service;

12 - and Modern Studies as part of general education and culture.

13 These reasons are put forward after an initial analysis of why Modern Studies have been neglected, and here the success and complacency of the British before the war, which Keynes was to bewail after, is the focus: "Our necessity (for Modern Studies) was not apparent; our profit was sufficient; the most part of us found in other ways such modest intellectual satisfaction as we craved" (Leathes Report 1918: 7). The five values identified by the Committee are thus expected to overcome the com-placency in different spheres:

- trade has been satisfactory but in fact hampered by lack of language study and the modern studies which language study facilitates;

- the whole world is a "manufactory of knowledge"1 and much of this is only available in other languages;

- lack of knowledge of other countries and peoples among the general public has been particularly evident during the war years and created problems of various kinds;

- this knowledge is particularly important in public service, in diplomacy and consular work, but also in ministries such as education, trade and agriculture where knowledge of what happens elsewhere is relevant to further development, and also in the armed services. (Leathes Report 1918: 15)

14 These are the first four reasons for valuing Modern Studies. The fifth reason, drawing on a tradition of 'liberal education', is contrasted with the first four since it adds a value to the practical demands of life which, as is strikingly stated, may be more valuable than life itself: "Culture and civilisation are by-products of life; but like some other by-products they may yield a greater return than the parent industry. What gives dignity and splendour to life may be more precious than the life itself" (ibid.).

What lies behind this are two key ideas: first, the notion of 'culture' which develops "the higher faculties, the imagination, the sense of beauty, and the intellectual comprehension" and, second, a comparison with Classical Studies as a proven source of cultural development, a comparison Leathes had already made in his What is Education? (1913: 79 ff.). This comparison is made with the intention of showing that Modern Studies can have the same function as Classical Studies. Here again the view that 
language is only a means to an end is emphasised, with the statement that Classical Studies "does not mean Latin and Greek", but rather the scholarship on which is based "an imaginative comprehension of two historic peoples" (Leathes Report 1918: 16) from whom we can learn a better way of life. This is what Modern Studies must aspire to for it is not sufficient to base Modern Studies on the practical reasons, important as these are.

Reception of the Report at the time is described by Bayley (1991: 15) as mixed; "while professional opinion welcomed the Report, official reaction was muted". On the whole, official response was in non-specific terms and left the responsibility of curricular change, if any, to teachers and others immediately concerned with curriculum. Nonetheless there was, at a national level, a subsequent implementation of institutional change including the Anglicisation of the teaching profession at universities - hitherto language teaching had been in the hands of native speakers - and the diversification of languages offered, recommendations made by the Report. Bayley concludes however that "the Leathes Report did not constitute an epoch in modern-language teaching". It supported changes already in progress, she argues, and supported the role of "Modern Studies" in secondary schools by its comparison of these with the liberal educational purposes of "Classical Studies".

\section{Preferred languages}

The Leathes Report as indicated above emphasised the importance of overcoming "ignorance of foreign countries and their peoples" (Bayley 1991: 11) ${ }^{1}$. At the same time, the Report's double focus on liberal education and on the instrumental or "practical" value of languages influenced its recommendations concerning which languages should be preferred. The preference was presented as a consequence of deciding which countries and peoples were important to "civilisation". There is an implicit contrast between the practical and the notion of "civilisation", and the committee emphasised the significance of the practical value by addressing this first, saying "we owe no apology for putting practical ends first. Knowledge and training have a clear value in the struggle for existence; and in order to live well it is first of all necessary to live" (Leathes 1918: 15). The phrase "we owe no apology" indicates however that they anticipate that there will indeed be criticism of this emphasis, which they want to anticipate and disarm, and they say categorically that the claims of Modern Studies cannot be based solely on practical needs. When the choice of languages for schools is discussed, the potential practical need for "non-European" languages gives way to "The Chief European Languages". It is here the notion of "civilisation" comes into play.

Even if the Report claims that "our literature is the richest in the world" (ibid.: 7), the deference to French as the preferred foreign language is unequivocal: "French is by far the most important language in the history of modern civilisation" (ibid.). ${ }^{2}$ It is evident from the explanation of the criteria that "civilisation" is understood as an improving and valorised concept, not a neutral designation. For despite the nod to "practical use" here, the further description of the role of France in the Enlightenment, of European dominance by France for 300 years in the arts, sciences and the fashions reveals the values of the Committee. Its description of England as a "pupil" of France - her rival only in literature - may have been inspired by the analogy of Rome as the pupil of 
Greece in the minds of people who wished to build Modern Studies on the model of Classical Studies.

When the practical reasons are listed, it is the importance of French as the language of diplomacy and as a lingua franca, combined with "physical propinquity". Reference to the Entente cordiale of 1904 remains implicit but there is explicit reference to the "special value" of French for Englishmen (sic: ignoring other Britons and women as was frequently the case). The final lines of the paragraph merit quotation in full:

Physical propinquity also gives French a special value for Englishmen; and recent calamities confronted and endured together should create an eternal bond of sympathy between the two nations. Fundamental diversity of character and temperament render mutual comprehension difficult, but once established it should serve to correct some of our national defects. In mere matter of language, as in other things, the two nations seem destined to serve as complementary one to the other. Our careless articulation may be corrected by the precise and studied utterance of the French: our modes of written expression might gain much from study of the perspicuous phrasing, logical construction, and harmonious proportions of their prose. From every point of view French is, for us above all, the most important of living tongues; it has, and it should retain, the first place in our schools and Universities. (Leathes Report 1918: 19) ${ }^{3}$

The implicit reference to national character in the first part of this quotation is a thread which runs throughout the Report and this is part of the notion of nation study to which we shall return.

Other languages are also considered in a way which reveals the representations of countries held in Britain at this time. German is considered next and perhaps unsurprisingly it is said that it is as yet too difficult to judge the "civilisation" of the current enemy. ${ }^{4}$ On the other hand the post-war importance of the country cannot be ignored:

After the war the importance of German must correspond with the importance of Germany. If Germany after the war is still enterprising, industrious, highly organised, formidable no less in trade than in arms, we cannot afford to neglect or ignore her for a moment; we cannot leave any of her activities unstudied. The knowledge of Germany by specialists will not suffice; it must be widespread throughout the people. A democracy cannot afford to be ignorant. (Leathes Report 1918: 19)

This "practical" argument for the study of German and Germany - here referred to as 'her' which is another indication of the notion of national character, as we shall see below - in the longer term, is complemented by the committee's view that commerce and "the settlement of pre-war accounts" will require language proficiency; the previous custom of employing German clerks would not be satisfactory. Almost simultaneously with the publication of the Leathes Report, Herbert Fisher, President of the Board of Education (i.e. Minister for Education), introduced the new Education Act and referred to the position of Germany post-war, which he believed would continue to be hostile and, he says, "that in itself constitutes a reason for giving the youth of our country the best preparation which ingenuity can suggest" (quoted in: Maclure 1965: 175). He was referring to the quality of education generally, and not language education, but it is within this general context that the statements of the Leathes Committee must be seen.

23 After France and Germany have each had a separate paragraph devoted to them, Italian, Spanish and Russian are treated in one paragraph together. The discussion 
mixes reference to lost opportunities for trade in Central and South America, in Russia and in Italy, with the analysis of the significance of their respective 'civilisation'. In the latter respect, the Report is unequivocal in its praise of Italy but in the final sentence of the paragraph states the preferred order of languages, taking into consideration the criterion of access to the 'manufactory of knowledge': "Finally, each and all of these countries make contributions to knowledge. Judged by this last criterion, Germany and France stand first, Italy third and Russia and Spain last" (Leathes Report 1918: 20). Italy was seen as the guardian of the traditions of ancient civilisations and a contributor to new developments in the sciences, medicine and engineering. Russia however is considered to have a difficult language, its recent literature being of little educational value and its history 'amorphous'.

The Committee conclude that all these languages should be studied in universities but, when they later turn to schools, they reinforce the priority of French while admitting that in a minority of schools "German or even Spanish or Italian" might be preferred.

The underlying question of the relationship of Modern Studies with Classical Studies comes to a head in the paragraphs on how many languages should be learnt at school and, if only one, which. The argument reposes on views about the optimum age for language learning: "It does not seem desirable that pupils who are to learn only one language should study Latin, which would deprive them of their only chance of becoming familiar with a living language during the years when living languages are most easily learnt" (ibid.: 28).

The foundation for modern languages in schools and universities, and the dominance of French in schools, is thus laid, but the view of language learning as a means to an endboth practical and liberal educational - is constantly reinforced.

\section{4. 'Nation study'}

We can now turn to the question of 'nation study', for in linking the discussion of which languages should be taught with the question of "civilisation", the focus is on individual countries, and on those countries immediately associated with the languages, Germany not Austria, France not Canada or French colonies for example. It is also clear from the beginning of the Report that, language study is a sine qua non for the study of the country, and, as we shall see, language study is frequently linked to the study of history.

For a more detailed contemporary discussion of the role of language study in relation to country study, or what the author in question calls 'nation-study', we first turn to an article, from four years later, on "The objectives of Russian study in Britain". The general position taken by the Leathes Report is evident in this article too, in its description of the work of the School of Slavonic Studies in London. The treatment of languages as a means to other ends is here coupled with its separation from "everything else":

First we separate from everything else the language, conceived purely as a means of study. This work should properly be done in a secondary school. As it is seldom done there, we have to do it in the universities; and, without this foundation, we cannot get on to anything else [...]. This separation once made, we are set free to put the further studies into their proper categories. (Pares 1922: 62) ${ }^{1}$ 
languages in the educational system of Great Britain" turns on the concept of "Modern Studies" in which the focus is on language-and-country. There are two foundation stones of the argument for modern studies: the analogy with classical studies and its role in liberal education and, secondly, the advantages which would accrue to Britain from improvements in language study and knowledge of other countries and peoples. The focus is on nations - Britain is assumed to be one 'nation' - both as objects of study and as the entity which will profit from study. This is explicable in terms of the need for "reconstruction" of Britain and its education system after the war; as we saw earlier the modern languages committee was just one of four committees under the aegis of a Reconstruction Committee. At the same time, however, in the world at large and also as a consequence of war, there was a renewed interest in internationalism - of which Keynes was an example - which decried the nationalism implicitly manifest in the Leathes Report and its concern that its analysis of "national needs" should lead to change. The question which arises is why the Leathes Report did not pay attention to internationalism.

\section{Internationalism and education}

"Internationalism" has not been widely treated in research and scholarship in education, nor as Kuehl (2009) says, in historiography. Kuehl shows that this has led to a lack of clarity in the definitions by historians and the same appears to be the case in education. One educationist ventures a definition which he hopes will be uncontroversial:

What I mean by internationalism is a readiness to act on the assumption that mankind as a whole is the proper society to have in mind for matters that cannot with safety or with such good effect be left exclusively within the domain of smaller social groups such as nations. I think it will be agreed that this is not an extravagant definition. (Elvin 1960: 16) 

but also in its nature cannot be considered except in relation to nationalism, which is a logically if not historically prior concept. ${ }^{1}$ Like nationalism, internationalism is a complex notion which, as Halliday says (1988: 188), is best seen as a "cluster concept" where there is no single core meaning. One element is "liberal internationalism" described by Halliday as "a generally optimistic approach based upon the belief that independent societies and autonomous individuals can through greater interaction and corporation evolve towards common purposes, chief among these being peace and prosperity" (Halliday 1988: 192).

raad, too, links liberal internationalism with "confidence in the rational and moral qualities of human beings" (2003: 39) and with "faith in progress towards more orderly social relations". From a historiographical perspective, Kuehl argues that liberal internationalism is a phrase, often employed without definition, that is associated with both pre-1914 and post-1918 periods, and, as indicated by Halliday, was associated with peace movements before the war and peace settlement after it. It is this kind of internationalism which we will find exemplified by some educationists in the 1920s, and which might have been expected to appear openly in the Leathes Report.

A second type of internationalism is what Holbraad (2003: 41) calls "socialist internationalism", in which he distinguishes "reformist" from "revolutionary". Others also refer to the link with socialism or to a "radical or revolutionary" internationalism (Halliday 1988: 188). The distinction between revolutionary and reformist is presented in terms of different kinds of response to nationalism. Where all other types of internationalism, including reformist socialism, accept nationalism as given, as an inevitability, revolutionary internationalism posits a basis in a non-nationalist solidarity of the proletariat, believing that class affinities are stronger than national allegiances. It is often argued however that class affinities did not withstand the demands of nationalism at the beginning of the 1914-18 war and undermined this nonnational type of internationalism (e.g. Lademacher 1988).

It is possible that the conflict between internationalism and nationalism - the inability to conceive the two as complementary - was the reason for the absence of internationalism in the Leathes Report; this is, however, speculation ${ }^{2}$. The Report was written and published whilst the war continued and though it looked ahead to a postwar world, nationalism was doubtless the dominant mode of thought. And this, even though rejection of war from an internationalist-socialist perspective was also manifest in the war zone itself and beyond: in France Barbusse's Le Feu was published in 1916 and an English translation appeared in 1917 in London and New York, and the Bolshevik revolution was in all the newspapers.

Whatever the discourse in the Leathes Committee may have been, what is more certain is that there were some educationists who were hoping that education would contribute to a lasting peace post-war. These tended to be individuals working independently, or small groups of teachers and other educationists, and manifestations of their activities appeared after the war rather than at the time the Leathes Report was being written ${ }^{3}$. For example, the conflict between nationalism and internationalism and the peace movement can be found in the rejection of nationalism in a report by Jonathan F. Scott, a teacher of history at the University of Michigan. In a tour of France, Germany and England in the early 1920s, Scott analysed the "Menace of Nationalism in Education" as he called his book, and found little evidence of peace education but at 
least some indications of a distrust of nationalist education. For example, he discusses the struggles over German education in the early post-war years. By 1923 in Prussia, education was in the hands of right wing politicians after an initial period of control from the left. He quotes from a decree of 1923 (Scott 1926: 104):

[...] all schools have a duty of fulfilling their tasks as German schools, while in suitable fashion they work for the intensification of German culture: to inspire youth with enthusiasm for German speech, the German race under German greatness of spirit is the more earnest task than ever before [...] today, more strongly than ever, the old demand holds, that every lesson shall be a German lesson.

In other parts of Germany the spirit was different and Scott (1926: 98) quotes a document from Baden where instruction is to be "in the spirit of German patriotism and international conciliation". However, despite the general international spirit of the programmes, he says that teaching itself was rather patriotic. In Britain he quotes a document on "training in citizenship" produced by the British Association for the Advancement of Science which refers to the importance of "national defence" and the need to be wary of how "the nations of the world watch each other with jealous, unscrupulous eyes" (ibid.: 146). Nonetheless, as is evident from his quotation, this same document has an internationalist dimension within or as an extension of the notion of patriotism:

[...] true patriotism recognises an ascending scale of duties from family to city, from city to country, from country to humanity; as the interest of family must give way to that of city or country, so must the interest of city or country give way to that of humanity. (British Association for the Advancement of Science 1920: 12)

This document then goes further in promoting the notion of 'international brotherhood' and proposes a syllabus which includes learning about the League of Nations (Scott 1926: 154). ${ }^{4}$

Another indication of a new attitude to education in Britain and more widely is the development of the New Education Fellowship from 1921. This group set out their principles for work, the final one being: "The new education fits the child to become not only a citizen capable of doing his duty is to his neighbours, his nation and humanity at large, but also a human being conscious of his personal dignity" (Boyd \& Rawson 1965: 74).

Boyd \& Rawson (1965) describe the founding of this group, their links to educationists internationally and their relationship to founders of progressive education. Historians of 'progressive education' (Röhrs \& Lenhart 1995) have argued that different groups in 'progressive education' had much contact across national frontiers and some specific educational philosophies and their realisations in practice - such as the Montessori and Waldorf schools - became international in their locations. However much of this only developed substantially from the 1920s. The early protagonists - from the 1880 s "neglected international relations, largely because they were preoccupied with the pioneering work that had to be performed first" (Röhrs 1995a: 18). From the 1920s, there were international conferences and visits by leading educationists to other countries - Dewey famously went to visit the Soviet Union for example - and from the mid-1920s there was a "recasting of the principles underlying the New Education Fellowship [...] [which] represented a clear perception of the dialogic relationship between nationally and internationally oriented education" (Röhrs 1995b: 185). 
In summary, we can see that the context in which the Leathes Report appeared was not without an internationalist approach to education, but that this really began to develop in Britain only 8-10 years later. The Leathes committee thought primarily in terms of nations and nation states, and the rivalries among them.

\section{Conclusion}

In conclusion, I would like to bring us to the present day where the national - and perhaps nationalist - perspective on language teaching is also strong. ${ }^{1}$ This has become all the more evident as curriculum documents begin to include reference not just to language but also to culture and identity. Two examples of curriculum statements will indicate this. First, in the Norwegian curriculum there has been an assertion that 'nation-study' - to use anachronistically the phrase from the 1920s - will "increase tolerance and respect", which are established purposes of foreign language education, but also strengthen learners' identification with their own 'culture', and here we note a change of terminology which would be worthy of further study in itself:

By learning [foreign] languages, pupils have opportunity to become familiar with other cultures. Such insight provides the basis for respect and increased tolerance, and contributes to other ways of thinking and broadens pupils' understanding of their own cultural belonging. In this way pupils' own identity is strengthened. [http://www.utdanningsdirektoratet.no/dav/ 78FB8D6918.PDF (put on the web January 2005)]

The Japanese case is perhaps nearer to the pre-occupations of the Leathes Report - and of H.A.L. Fisher as minister of education at the time - with economic competition. The strategic plan of 2002 to cultivate "Japanese with English abilities" links language teaching and learning to the economic purpose of education. It uses the discourse of human capital investment, and the plan is presented as part of a larger "strategy to enhance human potential". The motivation is explicitly "the progress of globalisation" with which "skills in English" are automatically associated:

With the progress of globalisation in the economy and in society, it is essential that our children acquire communication skills in English, which has become a common international language, in order for living in the 21st century (sic). This has become an extremely important issue both in terms of the future of our children and the further development of Japan as a nation.

[http://www.mext.go.jp/english/news/2002/07/020901.htm

(put on the web 12th July 2002)]

The particular character of English as a world language or lingua franca means that it is no longer linked with the study only of English-speaking countries, and may indeed be uncoupled from this association. But it would break the limits of this article to pursue in more detail the manifestations of nationalism - or internationalism - in language teaching policy in the present. 


\section{BIBLIOGRAPHIE}

BARBUSSE, Henri (1916). Le Feu. Paris: Flamarion.

BARBUSSE, Henri (1917). Under Fire. London: J.M. Dent.

BAYLEY, Susan (1991). “Modern Languages: An 'Ideal of Humane Learning': The Leathes Report of 1918”. Journal of Educational Administration and History, 23 (2), 11-24.

BIRN, Donald S. (1981). The League of Nations Union: its life and times 1918-1945. Oxford: Oxford University Press.

BOYD, William \& RAWSON, Wyatt (1965). The Story of the New Education. London: Heinemann. BRITISH ASSOCIATION FOR THE ADVANCEMENT OF SCIENCE (1920). Report of the Committee on Training in Citizenship. London: British Association for the Advancement of Science.

BUTTJES, Dieter (1990). “Culture in German Foreign Language Teaching: Making Use of an Ambiguous Past”. In Dieter Buttjes \& Michael Byram (eds.), Mediating Languages and Cultures: Towards an Intercultural Theory of Foreign Language Education. Clevedon: Multilingual Matters, 47-62.

ELVIN, H.L. (1960). "Nationalism and internationalism in education”. The School Review 68 (1), $1-22$.

HALLIDAY, Fred (1988). “Three concepts of internationalism”. International Affairs 64 (3), 187-198

HOLBRAAD, Carsten (2003). Internationalism and nationalism in European political thought.

Basingstoke: Palgrave.

JOHNSTON, Brenda, MITCHELL, Rosamund, MYLES, Florence \& FORD, Peter (2011). Developing student criticality in higher education. London: Continuum.

KEYNES, John Maynard (1920). The economic consequences of the peace. New York: Harcourt, Brace \& Howe [http://www.gutenberg.org/files/15776/15776-8.txt (consulted 30 April 2013)].

KRAMER, Jürgen (1997). British Cultural Studies. München: Fink.

KUEHL, Warren F. (2009). “Concepts of internationalism in history”. Peace and Change, 11 (2), 1-10.

LADEMACHER, Horst $\left({ }^{1} 1940,1988\right)$. "Kosmopolitismus, Solidarität und Nation. Einige Bemerkungen zum Wandel von Begriff und Wirklichkeit im internationalem Sozialismus”. In Frits van Holthoon \& Marcel van der Linden (eds.). Internationalism in the labour movement, 1830-1940, vol. II, 1988. Leiden/New York: Brill, 371-391.

[LEATHES REPORT:] The Report of the Committee Appointed by the Prime Minister to Enquire into the Position of Modern Languages in the Educational System of Great Britain (1918). London: HMSO.

LEATHES, Stanley Mordaunt (pseudonym: Numa MINIMUS) (1911). Vox Clamantis. Essays on collectivism. London: Macmillan \& Co.

LEATHES, Stanley Mordaunt (1913). What is Education? London: Bell and Sons.

MACLURE, John S. (1965). Educational documents. England and Wales 1816 to the present day. London: Methuen.

MODERN LANGUAGE ASSOCIATION of America and Nation Federation of Modern Language Teachers (1920). "Resolutions concerning the Teaching of Modern Languages". The School Review 28 (10), 776-778. 
OLMSTED, E.W. (1921). “A justification of Modern Languages in Our Schools”. The Modern

Language Journal 6 (1), 1-11.

PARES, Bernard (1922). “The Objectives of Russian Study in Britain”. The Slavonic Review, 1 (1), 59-72.

RÖHRS, Hermann (1995a). "Internationalism in progressive education and initial steps towards a world education movement”. In Röhrs \& Lenhart (eds.), 11-27.

RÖHRS, Hermann (1995b). “The New Education Fellowship: a international forum for progressive education”. In Röhrs \& Lenhart (eds.), 179-191.

RÖHRS, Hermann \& LENHART, Volker (eds.) (1995). Progressive education across the continents. (Heidelberger Studien zur Erziehungswissenschaft, 44.) Frankfurt a.M.: Lang.

SCOTT, Jonathan F. (1926). The menace of nationalism in education. London: Allen \& Unwin.

WILLIAMS, Raymond (1977). Marxism and Literature. Oxford: Oxford University Press.

\section{NOTES}

1.

Stanley Mordaunt Leathes (1861-1938) was a historian - one of the editors of and contributors to the Cambridge Modern History - and a civil servant, acting from 1910 to 1927 as 'First Civil Service Commissioner' (source: Oxford Dictionary of National Biography). He had written, in 1913, his What is Education?, where his liberal educational ideals are prominent. The Report which eventually took his name is written in much the same style and is very reminiscent of his 1913 book What is Education?

1. The notion of the 'knowledge economy' is thus anticipated but the view of what role language teaching and learning should play in this is different from what would be usually found today, where there is perhaps a greater assumption that all useful knowledge is to be found in English.

2. Bayley's general overall interpretation of the Leathes Report as 'elitist' is, however, exaggerated and merits further critique, which is however beyond the scope of this article.

1. This is a sentiment echoed in the USA in "resolutions concerning the teaching of languages" of the Modern Language Association in 1920 but here with the aim to overcome the isolation of the USA and its population rather than to provide a basis for development and profit for the country as was the focus in Great Britain. See Resolution 2 of the Modern Languages Association of America: "That, in view of the fact that the men and women of America should henceforth seriously endeavour to understand the psychology, the problems, and the achievement of the main foreign people, it is urgently desirable that a large proportion of high-school and college students should secure such a knowledge of the main foreign languages as will enable them to gain this understanding." (Modern Languages Association 1920: 776)

2. This sentiment had already been forcefully expressed by Leathes (1913: 84) in his discussion of the education of boys: "I think every boy who aspires to a secondary education, liberal or commercial, should learn at least one foreign language, and for many reasons, I think that universal language should be French."

3. The discussion of the role of Modern Languages which took place a few years later in the USA included some similar arguments, including reference to the nature of French language: "Of the three [French, German and Spanish] French is of the greatest linguistic value to Anglo-Saxons. In its clarity of expression, in its crispness of phrase, in its logical conciseness, in the precision and almost rigidity of its word usage, demanding the utmost definiteness of thought and allowing but little play to psychological nuance, it offers a most valuable corrective to our looser habit of 
thought and expression" (Olmsted 1921: 4). This author also cites the Leathes Report, in particular what it says about the importance of languages in gaining access to 'the manufactory of knowledge'.

4. This contrasts with the view expressed by Olmsted (1921) in the USA who probably found it easier to make such statements in a personal capacity: "It has always been a great regret to me that war hysteria should have led so many excellent persons to look upon these things in a prejudiced and narrow-minded way. No one can blame imperial Germany for her enormous crime against Civilization more bitterly than I, but neither France nor England took steps to abolish the study of the German language, though they felt the scourge of war more sharply than did we. Quite the contrary, as a matter of national defense from an intellectual, commercial, and military standpoint, the study of German is being fostered in both these countries. Monsieur Poincaré, ex-president of the French Republic, expresses himself as follows on this subject: To dominate German science, we need to know it. To maintain the independence and superiority of our literature, we must not close our eyes to foreign literatures, no more to the German than the rest." (Olmsted 1921: 8)

5. The reference to democracy here is part of a strand throughout the Report which belies Bayley's (1991) view of the Report as elitist.

1. A similar separation had been established in Cambridge in a two-part Tripos, with part I focused on practical mastery of a language and part II on foreign literature in cultural and historical context (Atkins \& Hutton 1920: 202 - 204, cited in Bayley 1991: 18). This position is largely maintained today in Cambridge, and a recent study of the teaching of languages in universities (Johnston et al. 2011: 116-117) also identified a broad division between 'language' and 'content' courses although the division is not rigid and may well not have been in the School of Slavonic studies in the 1920s. However the statement that "we follow the direct method" (Pares 1922: 62) may indicate a strong emphasis on oral skills above all else.

2. There is a strong parallel here with the notion of Landeskunde in the German tradition of foreign language teaching which came into being at the end of the $19^{\text {th }}$ century under the term of Realienkunde and became nationalist in the 1920s and even jingoist and racist in the 1930s under the label Kulturkunde (Buttjes, 1990; Kramer, 1997).

3. Here again there is anticipation of this in Leathes' What is Education? (1913: 111) where he argues for an enrichment of History by Modern Languages and vice versa, referring in particular to the study at the University of Cambridge: In the Historical Tripos no scholarly knowledge of any language is required; in the Modern Languages Tripos hardly any history except that of literature is taken into account. The study of history suffers in interest and illuminating force through the neglect of literature; the study of language and literature is a dead thing if separated from the general stream of human life.

1. According to Halliday (1988: 189), the term 'internationalism' was coined as a consequence of Marx's focus on proletarian unity: it was Marx's promotion of the International Workingmen's Association, the First International, in 1864 that lead to the coining of the word 'internationalism', the first recorded usage of which in English dates from 1877. However, Vincent (2002: 192) argues "internationalism was coined by Jeremy Bentham in the 1780 s to name a part of his legal theory which was concerned with the 'law of nations"'.

2. Leathes himself had written at length on socialism and 'collectivism' in a pseudonymously published work, Vox Clamantis in 1911. His focus remains however on the state, on the possibility of transition to a 'collectivist state' and he ultimately rejects its viability.

3. However, even at the time of the Leathes Report, ideas for the League of Nations were being widely discussed in Britain although there was little direct reference at this point to the role of education (Birn 1981).

4. On the other hand, the British Association for the Advancement of Sciences published in 1922 as a reprint from its Report of the Ninetieth Meeting (pp. 423-431 - an analysis of 'Imperial 
Citizenship' by the Right Hon. Lord Meston. Meston focuses on two dimensions of 'imperial citizenship': "Patriotism [...] the white flame which blazes out in protection of country or empire" and "Citizenship [...] the steady glow which warms men's hearts to a pride in their heritage and to a determination to do their share in making it still more worthy of living for or dying for" (1922: 423). He says this has been "temporarily dimmed by the reactions of the War" but that it must become the 'religion' for the future of what he tellingly calls "our Empire State", thus presenting the Empire as being one state, although the rest of his pamphlet is concerned with how the status of citizen can be administered throughout the empire. There is no hint of internationalism here.

1. At this point I hesitate to say whether this is a continuation or a renewal of concern with the nation and the identification with it of young people studying a foreign language since I have not followed the historical development since the 1920s. However as a teacher and teacher trainer, I am struck from my own experience by the novelty of the emphasis on learners' own national identification.

\section{RÉSUMÉS}

Le Leathes Report sur l'enseignement des langues modernes en Grande Bretagne fut publié en 1918 comme élément de la planification de changements dans le système d'éducation après-guerre. Le Rapport fit des recommandations à propos de la politique des langues, de leur offre à l'école et à l'université, des objectifs et de la méthodologie de leur enseignement et de la formation des professeurs. L'analyse de l'article présent focalise sur les recommandations concernant le choix de langues pour placer ensuite cette question dans le contexte plus large de l'éducation en Europe, et en Grande Bretagne en particulier, dans la période après-guerre. Une recommandation clé était l'utilisation de l'expression 'études modernes', au lieu de 'langues modernes', pour indiquer que l'étude d'une langue devrait avoir un but, y compris le but d'étudier d'autres pays, et non pas simplement l'étude de la langue en soi. Cette question est analysée dans le contexte du rôle de l'école dans la création du nationalisme. On s'attendrait à ce que les effets de la guerre auraient mené à une réduction du poids accordé dans le système d'éducation au développement de sentiments nationalistes et que l'enseignement de langues en serait un élément clé. Pourtant, malgré des appels à l'internationalisme et à la réduction du nationalisme, on n'en trouve aucune trace dans le Leathes Report en général ni dans les réflexions sur le choix de langues en particulier.

The Leathes Report on the teaching of modern languages in Britain was commissioned by the British government and published in 1918 as part of planning for post-war educational change. It made recommendations on matters of policy, methodology, teaching force and the choice of languages to be offered to learners in schools and universities. This analysis focuses on the report's recommendations concerning choice of language and then places this question in the broader context of education in post-war Europe and in Britain in particular. A key recommendation was the use of the term 'modern studies' instead of 'modern languages' to indicate that language study should be for a purpose, including the study of other countries, and not just a study for its own sake. This question is analysed in the context of the role of schools in creating nationalism. It might be expected that the effects of war would lead to a reduction in the emphasis given in schools to the development of nationalist sentiments and that modern language teaching might be seen as a key element. However although there were contemporary 
calls elsewhere in society for internationalism and a reduction of the emphasis on nationalism, there is no trace of this in the Leathes Report in general nor in the question of choices of languages in particular.

\section{INDEX}

Keywords : Foreign Language Teaching (20th century), Great Britain, Leathes Report, Language policy, Choice of languages, Nationalism, Internationalism, Intercultural education

Mots-clés : enseignement des langues étrangères (XXe siècle), Grande-Bretagne, Leathes Report, politique des langues, choix des langues, nationalisme, internationalisme, éducation interculturelle

\section{AUTEUR}

\section{MICHAEL BYRAM}

University of Durham, England

M.S.Byram@dur.ac.uk 